\title{
Environmental Isolate of Rahnella aquatilis Harbors Class 1 Integron
}

\author{
Ryszard Koczura $^{1} \cdot$ Joanna Mokracka $^{1} \cdot$ Nicoletta Makowska $^{1}$
}

Received: 12 May 2015/Accepted: 20 August 2015/Published online: 30 September 2015

(C) The Author(s) 2015. This article is published with open access at Springerlink.com

\begin{abstract}
The paper presents first description of class 1 integron in an environmental strain of Rahnella aquatilis, a rarely isolated Gram-negative bacterium of the family Enterobacteriaceae. The strain was isolated from the Warta river water, Poland. Class 1 integrase gene was detected by a PCR assay. Sequencing of the integron's variable region showed the presence of a dfrAl-aadAl gene cassette array. The integron was located in a 54-kbp plasmid that was transferable to Escherichia coli $\mathrm{J}-53$ recipient strain in a conjugation assay. The integron-bearing $R$. aquatilis strain was resistant to aminoglycosides, penicillins, trimethoprim, sulfamethoxazole, and trimethoprim/sulfamethoxazole. This paper confirms that water environment play a major role in the spread of integrons and, consequently, antimicrobial resistance, among bacteria of various genera.
\end{abstract}

\section{Introduction}

Rahnella aquatilis is a rarely isolated Gram-negative bacterium of the family Enterobacteriaceae. Rahnella aquatilis occurs mainly in freshwater; however, it is occasionally found in foods and human clinical specimens [6]. Clinical isolates have been cultured mostly from immunocompromised hosts [3]; however, a case of sepsis in a healthy patient has been described as well [3].

Ryszard Koczura

koczma@amu.edu.pl

1 Department of Microbiology, Faculty of Biology, Adam Mickiewicz University in Poznań, ul. Umultowska 89, 61-614 Poznań, Poland
Due to limited number of clinical cases and studies on antimicrobial susceptibility of environmental isolates, there is little data about antimicrobial resistance patterns and mechanisms of $R$. aquatilis. Resistance to amoxicillin, ampicillin, ticarcillin, cefotaxime, and cephalothin has been reported [3, 14, 17]. Rahnella aquatilis can also produce a class A extended-spectrum $\beta$-lactamase [14].

Mobile integrons play an important role in the spread of antibiotic resistance. They are responsible for integration and rearrangements of resistance determinants called gene cassettes. An integron consists of an integrase gene, a primary recombination site called $a t t I$, and a promoter $\mathrm{P}_{\mathrm{C}}$ that directs transcription of the integrated genes. Classes of integrons are distinguished upon the sequence of integrase gene. The most frequent are class 1 integrons that are considered to play the main role in the emergence and widespread of resistance genes [2].

Integrons have been detected in numerous Gram-negative species, including those of the family Enterobacteriaceae [12]. The aim of this study was to characterize a class 1 integron and corresponding antimicrobial resistance in an environmental $R$. aquatilis strain isolated from river water.

\section{Materials and Methods}

\section{Bacterial Strain}

A R. aquatilis strain designated MPU 658/3 was used in the study. It was cultured from the water of the Warta river taken in Sieradz, Poland. The strain was isolated on Brilliance E. coli/Coliform Selective Medium (Oxoid) and identified using multilocus sequence analysis (MLSA) of $a t p D, \operatorname{gyr} B, \inf B$, and $r p o B$ according to Brady et al. [1]. 
Rahnella aquatilis CIP $78-65^{\mathrm{T}}$ type strain was used as reference.

\section{Detection of Integrase Genes}

The presence of integron integrases in was determined using multiplex PCR method according to Dillon et al. [4] with primers complementary to class 1,2 , and 3 integrase genes. The amplification involved an initial denaturation $\left(94{ }^{\circ} \mathrm{C}, 5 \mathrm{~min}\right.$ ), followed by 30 cycles of denaturation $\left(94{ }^{\circ} \mathrm{C}, 1 \mathrm{~min}\right)$, annealing $\left(59^{\circ} \mathrm{C}, 1 \mathrm{~min}\right)$, and extension $\left(72{ }^{\circ} \mathrm{C}, 1 \mathrm{~min}\right.$ ), with a final extension step at $72{ }^{\circ} \mathrm{C}$ for 8 min. Escherichia coli AMU 2036/6 [8] and D1/7 [13] strain were used as positive controls for class 1 and class 2 integrase genes, respectively. Escherichia coli $\mathrm{K} 12$ was used as negative control.

\section{Analysis of the Variable Region of Class 1 Integron}

Variable part of the class 1 was amplified using primers complementary to its $5^{\prime}$ and $3^{\prime}$ conserved regions [9]. PCR amplification was conducted as follow: initial denaturation at $94{ }^{\circ} \mathrm{C}$ for $5 \mathrm{~min}$, and 30 cycles of $94{ }^{\circ} \mathrm{C}$ for $1 \mathrm{~min}$., $55^{\circ} \mathrm{C}$ for $1 \mathrm{~min} ., 72^{\circ} \mathrm{C}$ for $5 \mathrm{~min}$., and final elongation at $72{ }^{\circ} \mathrm{C}$ for $8 \mathrm{~min}$. The amplicon was sequenced in a 3130xl Genetic Analyzer (Applied Biosystems). Sequence data were assembled with DNA Baser (HeracleSoftware) and aligned with available GenBank data using Nucleotide basic local alignment search tool (BLAST). A gene cassette was identified if the similarity with GenBank data was equal or higher than $95 \%$.

All PCR reactions were done in a C1000 Touch thermal cycler (Bio-Rad). The products were separated in $1.5 \%$ agarose gel. Molecular weight of PCR products was determined with GelCompar II 3.5 software (Applied Maths). All experiments were done in duplicate.

\section{Antimicrobial Susceptibility Testing}

Antimicrobial susceptibility was determined with the standard disk diffusion method according to The European Committee on Antimicrobial Susceptibility Testing guidelines, with the 4.0 version of breakpoint tables for interpretation of zone diameters [5]. The following antimicrobials were used: amikacin $(30 \mu \mathrm{g})$, gentamicin $(10 \mu \mathrm{g})$, netilmicin $(10 \mu \mathrm{g})$, tobramycin $(10 \mu \mathrm{g})$, ampicillin $(10 \mu \mathrm{g})$, piperacillin $(30 \mu \mathrm{g})$, piperacillin/tazobactam $(36 \mu \mathrm{g})$, amoxicillin/clavulanic acid $(30 \mu \mathrm{g})$, cefepime $(30 \mu \mathrm{g})$, cefotaxime $(5 \mu \mathrm{g})$, ceftazidime $(10 \mu \mathrm{g})$, imipenem $(10 \mu \mathrm{g})$, aztreonam $(30 \mu \mathrm{g})$, ciprofloxacin $(5 \mu \mathrm{g})$, norfloxacin $(10 \mu \mathrm{g})$, chloramphenicol $(30 \mu \mathrm{g})$, streptomycin $(10 \mu \mathrm{g})$, trimethoprim $(5 \mu \mathrm{g})$, and trimethoprim/sulfamethoxazole $(25 \mu \mathrm{g})$. Production of extended-spectrum $\beta$-lactamases (ESBL) was checked by double-disk synergy test with ceftazidime, cefotaxime, and amoxicillin/clavulanic acid. All antibiotic disks were provided by Oxoid. Escherichia coli ATCC 25922 was used as a control strain.

The presence of $b l a_{\text {TEM }} \beta$-lactamase gene was determined by PCR assay with primers TEM-F and TEM-R according to Sáenz et al. [15]. PCR amplification was conducted as follow: initial denaturation at $94{ }^{\circ} \mathrm{C}$ for $5 \mathrm{~min}$, and 30 cycles of $94{ }^{\circ} \mathrm{C}$ for $1 \mathrm{~min}$., $60{ }^{\circ} \mathrm{C}$ for $1.5 \mathrm{~min} ., 72{ }^{\circ} \mathrm{C}$ for $5 \mathrm{~min}$., and final elongation at $72{ }^{\circ} \mathrm{C}$ for $8 \mathrm{~min}$.

\section{Plasmid Analysis}

Plasmid DNA was isolated with Plasmid Mini AX (A\&A Biotechnology) kit and separated in $0.7 \%$ agarose gel with E. coli V-517 plasmids used as molecular size markers. The DNA was transferred to Immobilon-NY+ membrane (Millipore) and fixed by UV cross-linking. Class 1 integrase gene was detected by digoxigenin-labeled intII probes with the use of DIG DNA Labeling and Detection Kit (Roche) according to manufacturer's instruction.

\section{Conjugation Assay}

Integron transfer ability was determined in broth-mating conjugation assay with E. coli $\mathrm{J}-53\left(\mathrm{Rif}^{\mathrm{R}}\right)$ as recipient strain. Briefly, overnight cultures of the donor and recipient strain were mixed in equal volumes, grown to mid-exponential phase, plated onto Mueller-Hinton agar plates containing rifampicin and sulfamethoxazole (all donor strains were sulfamethoxazole-resistant), and incubated for $24 \mathrm{~h}$ at $30^{\circ} \mathrm{C}$. Transconjugants were identified phenotypically and the presence of integrons was checked by the PCR assay described above.

\section{Results and Discussion}

Although $R$. aquatilis is a bacterium that naturally inhabitants freshwater ecosystems, it is capable of infecting humans, especially those immunocompromised or with an underlying chronic disease. Therefore, it is important to expand knowledge on its antimicrobial resistance and mechanisms that can lead to the spread of resistance.

The $R$. aquatilis MPU 658/3 strain used in our study was isolated from the water of the Warta river taken in Sieradz, Poland. PCR-screening for integrase genes showed the presence of intIl gene. On the contrary, the genome of $R$. aquatilis CIP $78-65^{\mathrm{T}}$ type strain does not contain an integrase gene [11]. Class 1 integrons are present in the genomes of clinical Gram-negative strains, but are also found in environmental isolates, albeit less frequently. They have been detected in strains of numerous species of 
the Enterobacteriaceae family, including Escherichia spp., Citrobacter spp., Enterobacter spp., Klebsiella spp., Kluyvera spp., Morganella spp., Pantoea spp., Proteus spp., Salmonella spp., and Serratia spp. [10, 12].

Amplification of the variable region of the class 1 integron of the $R$. aquatilis yielded a $1.6-\mathrm{kbp}-$ long PCR product. Sequencing of the amplicon showed that it contained two genes: dfrAl and aadAl (Fig. 1). The former codes for dihydrofolate reductase conferring resistance to trimethoprim, whereas the latter encodes aminoglycoside adenylyltransferase responsible for resistance to streptomycin and spectinomycin. The $d f r A l-a a d A l$ gene cassette array is common and may be present in up to $20 \%$ of class 1 integron-harboring isolates [12].

The $R$. aquatilis MPU 658/3 strain was resistant to aminoglycosides (streptomycin, and amikacin), penicillins (ampicillin, piperacillin), dihydrofolate reductase inhibitors (trimethoprim), sulfonamides (sulfamethoxazole), and trimethoprim/sulfamethoxazole. Apart from intrinsic resistance characteristic for the members of the Enterobacteriaceae family, $R$. aquatilis is also naturally resistant to ticarcillin and cefuroxime [16]. Although the resistance pattern was relatively narrow, it indicated multidrug-resistant phenotype typical for bacteria carrying integrons [12]. The resistance of R. aquatilis MPU 658/3 to aminoglycosides, trimethoprim, sulfamethoxazole, and trimethoprim/sulfamethoxazole was related to the class 1 integron due to the presence of $d f r A l$ aadA gene cassette array, and sull gene in the $3^{\prime}$ conserved segment. Resistance to penicillins was determined by the presence of a of $b l a_{\text {TEM }}$ gene.

The $R$. aquatilis MPU 658/3 strain did not produce an extended-spectrum $\beta$-lactamase. ESBL phenotype in R. aquatilis can be mediated by RAHN-1 or RAHN-2 class A $\beta$-lactamases encoded by genes located in the chromosome [14].

The class 1 integron of $R$. aquatilis MPU 658/3 was located in a $\sim 54-\mathrm{kbp}$ plasmid that was transferable to $E$. coli $\mathrm{J}-53$ recipient strain. The transconjugant strain was positive for the presence of class 1 integrase and was resistant to streptomycin, ampicillin, piperacillin, trimethoprim, sulfamethoxazole, and trimethoprim/sulfamethoxazole. The transferred resistance to streptomycin, trimethoprim, sulfamethoxazole, and trimethoprim/sulfamethoxazole was related to the class 1 integron due to the presence of $d f r A l$-aadA gene cassette array, and sull gene in the $3^{\prime}$ conserved segment.

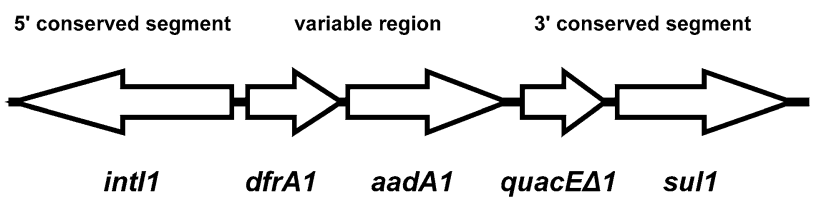

Fig. 1 Genetic structure of class 1 integron in Rahnella aquatilis strain MPU 658/3
To sum up, we describe for the first time a class 1 integron in an environmental strain of $R$. aquatilis. This finding confirms that water environment play a major role in the spread of integrons and, consequently, antimicrobial resistance, among bacteria of various genera.

Acknowledgments This work was funded by Grant No. N N305 035337 from the Polish Ministry of Science and Higher Education.

\section{Compliance with Ethical Standards}

Conflict of interest The authors declare that they have no conflict of interest.

Open Access This article is distributed under the terms of the Creative Commons Attribution 4.0 International License (http://crea tivecommons.org/licenses/by/4.0/), which permits unrestricted use, distribution, and reproduction in any medium, provided you give appropriate credit to the original author(s) and the source, provide a link to the Creative Commons license, and indicate if changes were made.

\section{References}

1. Brady C, Cleenwerck I, Venter S, Vancanneyt M, Swing J, Coutinho T (2008) Phylogeny and identification of Pantoea species associated with plants, humans and the natural environment based on multilocus sequence analysis (MLSA). Syst Appl Microbiol 31:447-460

2. Cambray G, Guerout A, Mazel D (2010) Integrons. Annu Rev Genet 44:141-166

3. Chang CL, Jeong J, Shin JH, Lee EY, Son HC (1999) Rahnella aquatilis sepsis in an immunocompetent adult. J Clin Microbiol 37:4161-4162

4. Dillon B, Thomas L, Mohmand G, Zelynsky A, Iredell J (2005) Multiplex PCR for screening of integrons in bacterial lysates. J Microbiol Methods 62:221-232

5. EUCAST (2014) Breakpoint tables for interpretation of MICs and diameter zones. Version 4.0. European Committee on Antimicrobial Susceptibility Testing. http://www.eucast.org/fileadmin/ src/media/PDFs/EUCAST_files/Breakpoint_tables/Breakpoint_ table_v_4.0.pdf

6. Kämpfer P (2005) Genus Rahnella. In: Brenner DJ, Krieg NR, Staley JR (eds) Bergey's manual of systematic bacteriology. The Proteobacteria, Part B: Gammaproteobacteria, vol 2. Springer, New York, pp 759-763

7. Koczura R, Mokracka J, Jabłońska L, Gozdecka E, Kubek M, Kaznowski A (2012) Antimicrobial resistance of integron-harboring Escherichia coli isolates from clinical samples, wastewater treatment plant and river water. Sci Total Environ 414:680-685

8. Koczura R, Semkowska A, Mokracka J (2014) Integron-bearing Gramnegative bacteria in lake waters. Lett Appl Microbiol 59:514-519

9. Lévesque C, Piché L, Larose C, Roy PH (1995) PCR mapping of integrons reveals several novel combinations of resistance genes. Antimicrob Agents Chemother 39:185-191

10. Machado E, Ferreira J, Novais Â, Peixe L, Cantón R, Baquero F, Coque TM (2007) Preservation of integron types among Enterobacteriaceae producing extended-spectrum $\beta$-lactamases in a spanish hospital over a 15 -year period (1988 to 2003). Antimicrob Agents Chemother 51:2201-2204

11. Martinez RJ, Bruce D, Detter C, Goodwin LA, Han J, Han CS, Held B, Land ML, Mikhailova N, Nolan M, Pennacchio L, 
Pitluck S, Tapia R, Woyke T, Sobecky PA (2012) Complete genome sequence of Rahnella aquatilis CIP 78.65. J Bacteriol 194:3020-3021

12. Mokracka J, Koczura R, Kaznowski A (2012) Multiresistant Enterobacteriaceae with class 1 and class 2 integrons in a municipal wastewater treatment plant. Water Res 46:3353-3363

13. Mokracka J, Koczura R, Kaznowski A (2012) Transferable integrons of Gram-negative bacteria isolated from the gut of a wild boar in the buffer zone of a national park. Ann Microbiol 62:877-880

14. Ruimy R, Meziane-Cherif D, Momcilovic S, Arlet G, Andremont A, Courvalin P (2010) RAHN-2, a chromosomal extended- spectrum class A $\beta$-lactamase from Rahnella aquatilis. J Antimicrob Chemother 65:1619-1623

15. Sáenz Y, Brinas L, Domínguez E, Ruiz J, Zarazaga M, Vila J (2004) Mechanisms of resistance in multiple-antibiotic-resistant Escherichia coli strains of human, animal, and food origins. Antimicrob Agents Chemother 48:3996-4001

16. Stock I, Grüger T, Wiedemann B (2000) Natural antibiotic susceptibility of Rahnella aquatilis and R. aquatilis-related strains. J Chemother 12:30-39

17. Tash K (2005) Rahnella aquatilis bacteremia from a suspected urinary source. J Clin Microbiol 43:2526-2528 